\title{
Effect of bradyrhizobial inoculation on growth and seed yield of mungbean in Fluvisol and Humofluvisol
}

\author{
Dušica Delić ${ }^{1 \star}$, Olivera Stajković-Srbinović ${ }^{1}$, Djordje Kuzmanović ${ }^{1}$, Nataša Rasulić ${ }^{1}$, \\ Vesna Mrvić ${ }^{1}$, Srdjan Andjelović ${ }^{2}$ and Jelena Knežević-Vukčević ${ }^{3}$ \\ ${ }^{1}$ Institute for Soil Science, Teodora Drajzera 7, Belgrade, Serbia. \\ ${ }^{2}$ Selsem d.o.o., Belgrade, Serbia. \\ ${ }^{3}$ Faculty of Biology, University of Belgrade, Serbia.
}

Accepted 19 September, 2011

\begin{abstract}
Nitrogen fixing effectiveness of selected Bradyrhizobium spp. strains to mungbean, Vigna radiata L. for better quantity and quality of grain and shoot dry matter was investigated in field conditions in two soil types with the aim of introducing of mungbean as a new crop in Republic of Serbia. Seed inoculation was done with four active strains both individually and in combination with fertilization of $20 \mathbf{~ k g ~ N ~ h a}^{-1}$. Quantity and quality of yield of grain and shoot dry matter was higher in Fluvisol than in Humofluvisol. On the both soil types, seed inoculation with and without $20 \mathrm{~kg} \mathrm{~N} \mathrm{ha}^{-1}$ produced significantly higher grain yield (11-59\%) and shoot dry weight (13-48\%) as well as total $N$ content and protein yield in respect to untreated control (Ø). The strains, soil types, mineral $\mathbf{N}$ and their interaction significantly influenced shoot dry matter and grain yield. According to high quantity and quality of grain and shoot dry matter yield, application of $B$. japonicum strain 542 in combination with $20 \mathrm{~kg} \mathrm{~N} \mathrm{ha}^{-1}$ could replace fertilization of $40 \mathrm{~kg} \mathrm{~N} \mathrm{ha}^{-1}$ and would be applied in production of mungbean.
\end{abstract}

Key words: Bradyrhizobium strains, Vigna radiata L., symbiotic $\mathrm{N}$ fixation, inoculation, yield.

\section{INTRODUCTION}

Mungbean, Vigna radiata (L.) Wilczek is an ancient and well-known pulse crop in Asia, particularly in the Indian subcontinent. It is now becoming popular in the other countries as a cheap, high quality and protein-rich food which can be considered as healthy nourishment. This annual legume is known to have high nutrient values with excellent source of vegetable protein (seeds and sprouts contain to $28 \%$ of proteins). Seeds contain $60-65 \%$ carbohydrates, low content of fat (1-1.5\%) and 3.5-4.5\% fibre. Sprout is rich in vitamins, minerals and amino acids (especially lizin). Mungbean is considered as a substitute of animal protein and forms a balanced diet when used with cereals (Khan and Malik, 2001; Anjum et al., 2006; Mansoor, 2007).

This legume species is used primarily as human food, but also it can be used as forage and green manure (Reedy et al., 1986). Predominantly, the grain that is

\footnotetext{
*Corresponding author. E-mail: vukmirdusica@yahoo.com. Tel:/Fax: +381112667 123 .
}

consumed, but green matter and immature pods as well. Seed is more palatable, easy digestible and non-flatulent than other pulse allowing mungbean to consume in vegetarian and dietetic nourishment (Abbas et al., 2011). In addition, it contains isoflavonoids having estrogens and antioxidant activities that can be used in prevention of much disease such as cancer (Brouns, 2002). Further more, it exhibits antimicrobial and insecticidal activities (Sheteawi and Tawfik, 2007).

Although mungbean is grown mostly for grain production, early season forage production of mungbean can be followed by its grain production; it is dual-purpose of mungbean (EI Karamany, 2006). Mungbean can produce a large amount of biomass (about $9 \mathrm{t} \mathrm{ha}^{-1}$ ) and can be recovered after grazing to yield abundant grain. It has the potential of producing higher seed yield from 1295 to $2961 \mathrm{~kg} \mathrm{ha}^{-1}$ depending on genotypes studied (EI Karamany, 2006; Rafiei, 2009; Tien et al., 2002; Ullah et al., 2011).

High economic importance of mungbean, especially in the developing countries, is reflected in many ways as ability of cultivation in arid areas, growth on marginal 
lands as well as the improvement of soil quality due to ability of symbiotic nitrogen (N) fixation (SNF). Thanks to the ability of rhizobial bacteria to fix $\mathrm{N}$ from the air $\left(\mathrm{N}_{2}\right)$ in symbiosis with legumes, huge natural source of $\mathrm{N}$ from the air can be taken up from this symbiotic association. This ability leads to decrease or absence of $\mathrm{N}$ mineral fertilizer application in the field (Rahman et al., 2002; Abbas et al., 2011).

According to some field trial, application of $30-50 \mathrm{~kg}$ mineral $\mathrm{N}$ ha $^{-1}$ resulted in significant increases of mungbean productivity (Ashraf et al., 2003; Rahman et al., 2002). Amount of $\mathrm{N}$ mineral fertilizer applied depends on abiotic and biotic factors. One of the principle ways to avoid or decrease environmental pollution associated with really expensive mineral $\mathrm{N}$ fertilizer is to insist on maximal use of seed inoculation as microbiological $\mathrm{N}$ fertilizer. Mungbean in symbiosis with effective Rhizobium and Bradyrhizobium spp. can fix $30-60 \mathrm{~kg} \mathrm{~N}$ $\mathrm{ha}^{-1}$ depending on agro ecological conditions (Mansoor, 2007). Applying seed inoculation with effective rhizobial strains is important agronomic measure which improves intensity of SNF and satisfies plant need for $\mathrm{N}$ (Vlassak and Vanderleyden, 1997; Herridge et al., 2005).

It is known that indigenous rhizobial populations in symbiosis with host plant fix $\mathrm{N}_{2}$ with different efficiency depending of their density and activity (Mpepereki et al., 2000; Musiyiwa et al., 2005).

Therefore, only highly effective rhizobial strains as plant inoculants in form of microbiological $\mathrm{N}$ fertilizer can increase production of legumes so therefore selection of highly effective strains is necessary process and important area of investigation. Seed inoculation with strains prior to sowing allows a reduction in $\mathrm{N}$ mineral fertilization, increases plant and seed quality and yield as well as decreases susceptibility to environmental stress (Tien et al., 2002; Herridge et al., 2005).

The characteristics of mungbean as healthy food as well as its grate similarity of growing way with soybean along with our intention for expansion of sustainable agriculture production (Myers, 2000) indicate that $V$. radiata should be introduced into agricultural production in temperate continental climate zone that Serbia belongs.

Nitrogen fixing effectiveness of selected bradyrhizobium strains to mungbean for better quantity and quality of grain and shoot dry matter was investigated in two different soil types in field conditions. The aim of this field research was to study the possibility of cultivation of mungbean (forage and seed) in temperate climate in Serbian soils, by applying seed inoculation with selected highly effective rhizobial strains.

\section{MATERIALS AND METHODS}

\section{Bacterial strains and host plant}

Bradyrhizobium japonicum strains 525, 526, 542 and 532 and
Bradyrhizobium sp. isolate Knj from Collection of Institute of Soil Science, Belgrade were applied. The bradyrhizobial cultures were maintained on yeast mannitol agar (YMA) (Vincent, 1970). Mungbean, $V$. radiata was used as the host-plant. The seed of mungbean (domestic population) was obtained from the "Selsem", company for breeding and seed production (Belgrade, Serbia).

\section{Inoculum preparation}

Each of single bradyrhizobial strains was grown in $100 \mathrm{ml}$ liquid Yeast Extract Mannitol medium (YMB) (Vincent, 1970) with shaking, for $72 \mathrm{~h}$ at $28^{\circ} \mathrm{C}$ up to approximately $10^{9}$ cell $\mathrm{ml}^{-1}$ determined by colony-plating of dilutions. The culture of $40 \mathrm{ml}$ of each single bradyrhizobial inoculum was mixed with $100 \mathrm{~g}$ sterile ground peat as inoculum carrier and packed in polyethylene bags. All operations were carried out aseptically in a laminar flow chamber. After period of incubation (15 days) single inoculums consisted of approximately $10^{9}$ bradyrhizobia g $^{-1}$ of peat (Somasegaran and Hoben, 2004).

\section{Identification and characterization of soil types of field sites}

The trial was set up at two field sites: Ratare $(Y=7430288$, $\mathrm{X}=4945438)$ and Grabovac ( $\mathrm{Y}=7429637, \mathrm{X}=4942333)$ locations. On the both field sites, soil profiles were done to determine type of soil and soil samples were taken from every generic horizon. The fallowing analysis were determined: granulometric composition (combined method of sieving and pipette method), $\mathrm{pH}$ in $\mathrm{H}_{2} \mathrm{O}$ and $\mathrm{pH}$ in $1 \mathrm{M} \mathrm{KCl}$ (electrometrically), $\mathrm{CaCO}_{3}$ (volumetrically, using Scheibler calcimeter), humus (CNS Elemental Analyzer Vario EL III).

Using both field and laboratory data the soils have been classified according to national classification (Škorić et al., 1985) as Fluvisol soil type (Ratare) and Humofluvisol (meadow soils) (Grabovac) that corresponds to Fluvisol and Fluvisol Clayic, respectively (IUSS Working Group WRB, 2007). Fluvisol has been protected from flooding for a long time. Experimental field on the Fluvisol had clayed loam texture with the following characters in Amo horizon: sand $31.3 \%$, silt $32.3 \%$, clay $36.4 \%$, pH 6.95 , organic matter $4.23 \%, \mathrm{CaCO}_{3} 0.42 \%$. The Humofluvisol had heavy clay texture with the following characters also, in Amo horizon: Sand $22.5 \%$, silt $30.6 \%$, clay $46.9 \%$, pH 6.82 , organic matter $4.21 \%$, $\mathrm{CaCO}_{3} 1.26 \%$ ). Soil characteristics of the field sites are listed in Table 1.

\section{Agro ecological conditions and field history}

Field trial was set up in 2007 in the two field sites of the central part of Serbia with temperate continental climate. Meteorological data for experimental year were based on data from "Surcin" Geometeorological station, Republic Hydrometeorology Department of Republic of Serbia, Belgrade (www.hidmet.sr.gov.yu). In 2007 average annual temperature of air was $13.2^{\circ} \mathrm{C}$ and during the growing period (from March to October) average monthly temperature was $23.2^{\circ} \mathrm{C}$ with maximum in July $31.4^{\circ} \mathrm{C}$. In Jun, July and August average maximal extreme temperature 29.0, 32.0 and $30.3^{\circ} \mathrm{C}$, respectively. In this year total amount of rainfall was 770.9 $\mathrm{mm}$ and during the growing period was $532.3 \mathrm{~mm}$ with two long dry periods: the fist was in the middle of April and the second one was from the end of June to the beginning of August (Figure 1).

Mungbean has never been cultivated on Ratare and Grabovac locations. In addition, in the past 10 years no legumes have been grown in Ratare, while in Garbovac legumes have never been cultivated before. In the experimental sites previous crops were some vegetables. Before sowing and during vegetation mineral manure was not added as well as pesticides. 
Table 1. Granulametric content and chemical properties of soil samples at field location.

\begin{tabular}{|c|c|c|c|c|c|c|c|c|c|c|c|c|}
\hline \multirow[b]{2}{*}{ Type of soil/field location } & \multirow[b]{2}{*}{ Horizontal } & \multirow[b]{2}{*}{ Depth cm } & \multicolumn{3}{|c|}{ Granulometric content } & \multirow[b]{2}{*}{$\begin{array}{c}\mathrm{pH} \\
(\mathrm{KCl})\end{array}$} & \multirow[b]{2}{*}{$\begin{array}{c}\mathrm{CaCO}_{3} \\
\%\end{array}$} & \multirow[b]{2}{*}{$\begin{array}{c}\text { Humus } \\
\%\end{array}$} & \multirow[b]{2}{*}{$\mathbf{N} \%$} & \multirow{2}{*}{$\begin{array}{c}\mathrm{NH}_{4}-\mathrm{N}+ \\
\mathrm{NO}_{3}-\mathrm{N} \\
\mathrm{mg} / \mathrm{kg} \\
\end{array}$} & \multirow[b]{2}{*}{$\begin{array}{c}\mathrm{P}_{2} \mathrm{O}_{5} \\
\mathrm{mg} / 100 \mathrm{~g}\end{array}$} & \multirow[b]{2}{*}{$\begin{array}{c}\mathrm{K}_{2} \mathrm{O} \\
\mathrm{mg} / 100\end{array}$} \\
\hline & & & $\begin{array}{l}\text { Total send } \\
>0.02 \mathrm{~mm}\end{array}$ & $\begin{array}{c}\text { Silt } \\
0.002-0.02 \mathrm{~mm} \\
\end{array}$ & $\begin{array}{c}\text { Clay } \\
<0.002 \mathrm{~mm} \\
\end{array}$ & & & & & & & \\
\hline \multirow{4}{*}{ Humofluvisol Grabovac } & Amo & $0-43$ & 22.5 & 30.6 & 46.9 & 6.82 & 1.26 & 4.21 & 0.219 & 25 & 28.10 & 22.40 \\
\hline & AmoC & $43-85$ & 21.3 & 24.7 & 54.0 & 6.89 & 0.85 & 1.52 & 0.079 & / & 0.38 & 11.80 \\
\hline & C & 85-105 & 21.4 & 25.5 & 53.1 & 7.21 & 1.27 & 1.06 & 0.055 & l & 0.32 & 9.20 \\
\hline & CG & $105-125$ & 25.6 & 25.9 & 48.5 & 7.32 & 3.39 & 1.09 & 0.057 & / & 0.33 & 9.20 \\
\hline \multirow{4}{*}{ Fluvisol Ratari } & Amo & $0-54$ & 31.3 & 32.3 & 36.4 & 6.95 & 0.42 & 4.23 & 0.220 & 25 & 17.03 & 38.80 \\
\hline & $\mathrm{C} 1$ & $54-94$ & 28.8 & 31.3 & 39.9 & 6.71 & 0.42 & 1.73 & 0.090 & I & 0.75 & 14.00 \\
\hline & $\mathrm{C} 2$ & $94-115$ & 42.0 & 33.5 & 24.5 & 7.32 & 22.85 & 1.09 & 0.057 & I & 0.30 & 7.60 \\
\hline & C3 & $115-125$ & 60.8 & 23.4 & & 7.51 & 25.81 & 0.65 & 0.034 & I & 1.90 & 5.50 \\
\hline
\end{tabular}

- Temperatures $\longrightarrow$ T max - - - - Precipitation

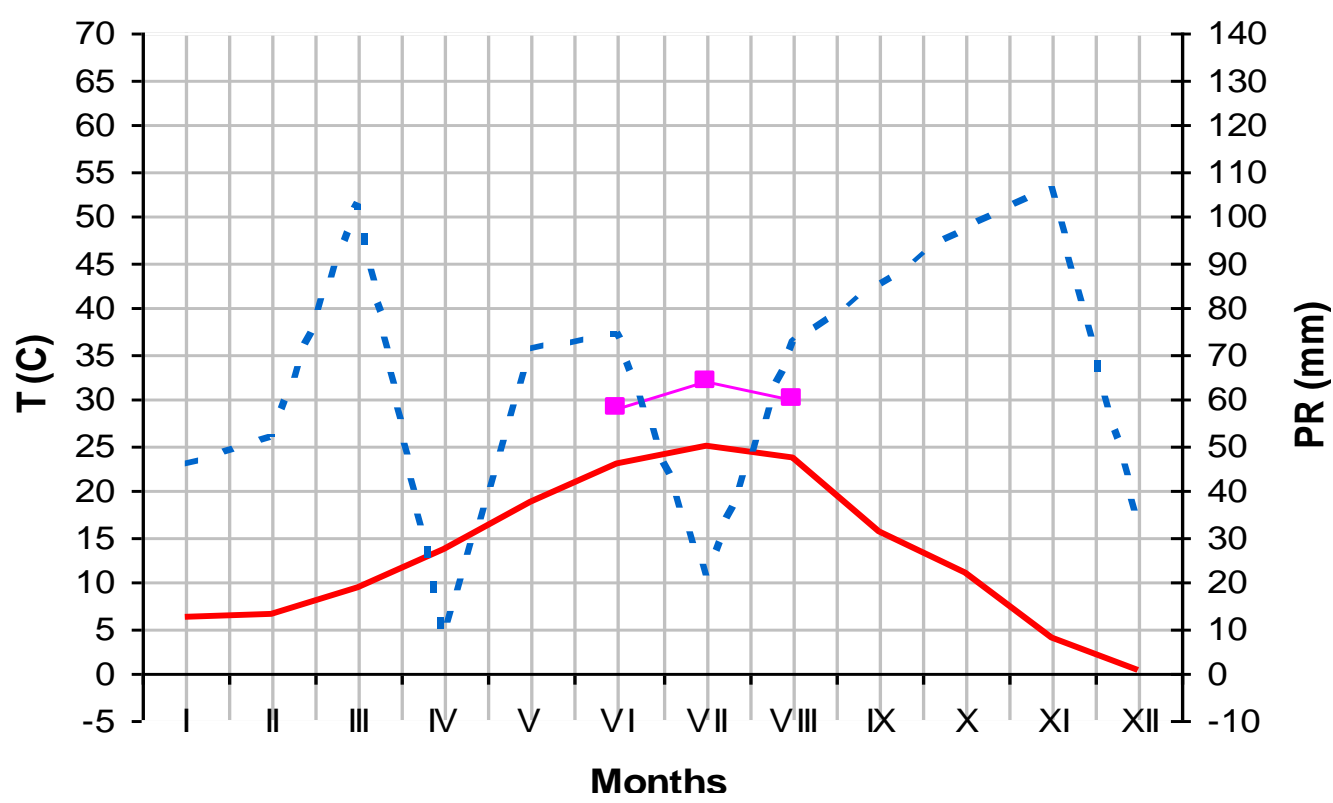

Figure 1. Climate diagram(Walter,1970) for 2007; average precipitations (PR), average day temperatures $(T)$ and average maximum day temperatures ( $T$ max) in Republic of Serbia. 


\section{Experimental design of field trial}

The trial was designed with eight inoculated and three uninoculated controlled treatments. Inoculated treatments consisted of 4 only inoculated treatments with single bradyrhizobial strains $(542,526$, 525, and $\mathrm{Knj}$ ) and 4 combined treatments of these single strains and mineral $\mathrm{N}$ rate of $20 \mathrm{~kg} \mathrm{~N}^{-1}$. Inoculated treatments were compared with 3 controlled uninoculated treatments $\left(\varnothing, \mathrm{N}_{20} \varnothing\right.$ and $\mathrm{N}_{40} \varnothing$ ): untreated control- $\varnothing$ (without any treating), fertilized control with $20 \mathrm{~kg} \mathrm{~N} \mathrm{ha}^{-1}-\mathrm{N}_{20} \varnothing$ and fertilized control with $40 \mathrm{~kg} \mathrm{~N} \mathrm{ha}^{-1}-\mathrm{N}_{40} \varnothing$. Fertilization was applied as potassium ammonium nitrate-KAN $(27 \% N)$.

The experiments were laid out in completely randomized system with three replicates. Experimental plot was $0.9 \mathrm{~m} \times 2 \mathrm{~m}$. Seeds were sown in the first week of May maintaining $30 \mathrm{~cm}$ row-to-row and $10 \mathrm{~cm}$ plant-to-plant spacing. Each plot was planted as three rows of $2 \mathrm{~m}$ length.

\section{Measurement of plant parameters}

Forty-two days after sowing (DAS) samples of 10 plants were randomly collected from each plot to evaluate root nodulation. Then, 67 DAS plants from the first row of experimental plots were harvested to determine quantity, shoot dry weight (SDW) as well as quality, \%N in shoot dry matter (SDM). At the end of September, 120 DAS (at maturity stage) the crop was harvested to measure grain yield; the matured pods were collected by hand plucking from the plant of each treatments and air drying and threshing were done.

The percentage of shoot and grain nitrogen was determined by CNS Elemental Analyzer (Vario EL III) and it was used to calculate total and fixed $\mathrm{N}$ content as well as protein yield in $\mathrm{kg} \mathrm{ha}^{-1}$. Fixed $\mathrm{N}$ was calculated by subtracting total $N$ content of control- $\varnothing$ from total $\mathrm{N}$ content of each treatment inoculated (Vincent, 1970). Fixed $\mathrm{N}$ as percentage of $\mathrm{N}$ accumulated amount (total $\mathrm{N}$ content) was determined as the amount of fixed $\mathrm{N} \times 100 /$ the amount of total $\mathrm{N}$ content (Remans et al., 2008).

Percentage of yield increase represented percentage of increase of a grain yield as well as a shoot dray weight yield in respect to control- $\varnothing$ expressed as $100 \%$.

\section{Statistical analysis}

All data were subject to ANOVA using the statistical analysis system (SPSS). Means of all treatments were calculated and the differences were tested for significance using the LSD test at the 0.5 probability level. Correlation coefficients were calculated to study the associative relations among the measured traits.

\section{RESULTS}

\section{Grain yield}

The effect of bradyrhizobial inoculation on quantity and quality of grain yield of mungbean in the two soil types, the Fluvisol and Humofluvisol, was estimated and results were presented in Table 2. Seed inoculation was done with four active bradyrhizobial strains both individually and in combination with $20 \mathrm{~kg} \mathrm{~N} \mathrm{ha}^{-1}$ in the form of $\mathrm{N}$ mineral fertilizer.

In Fluvisol soil, among all inoculated treatments the greatest grain yield was recorded by seed inoculation with strain 542 in combination with $\left(1.301 \mathrm{t} \mathrm{ha}^{-1}\right)$ and without $20 \mathrm{~kg} \mathrm{~N} \mathrm{ha}^{-1}\left(1245 \mathrm{~kg} \mathrm{ha}^{-1}\right)$. Results showed that there were no significant differences between these two treatments as well as fertilized control $\left(\mathrm{N}_{40} \varnothing\right)$ in which $\mathrm{N}$ mineral fertilizer of $40 \mathrm{~kg} \mathrm{~N}^{-1}\left(1325 \mathrm{~kg} \mathrm{ha}^{-1}\right)$ was applied. Significantly lower grain yield was obtained by inoculation with the remaining strains $526, \mathrm{Knj}$ and 525 with and without application of $\mathrm{N}$ mineral fertilizer (1007$1167 \mathrm{~kg} \mathrm{ha}^{-1}$ ) as well as in fertilized control with $20 \mathrm{~kg} \mathrm{~N}$ ha $^{-1}\left(\mathrm{~N}_{20} \varnothing\right)\left(1028 \mathrm{~kg} \mathrm{ha}^{-1}\right)$.. Untreated control treatment- $\varnothing$ gave the lowest grain yield $\left(816 \mathrm{~kg} \mathrm{ha}^{-1}\right)$, significantly lower from all the other treatments.

In Humofluvisol soil, the grain yield of all treatments was considerably lower by $15-43 \%$ than that in the Fluvisoli, it varied from 710 to $930 \mathrm{~kg} \mathrm{ha}^{-1}$. The greatest yield obtained by inoculation with strain 542 in combination with $20 \mathrm{~kg} \mathrm{~N} \mathrm{ha}^{-1}\left(930 \mathrm{~kg} \mathrm{ha}^{-1}\right)$ was not significantly higher than grain yield obtained with 542 strain $\left(910 \mathrm{~kg} \mathrm{ha}^{-1}\right)$ as well as in $\mathrm{N}_{40} \varnothing$ fertilized control $\left(897 \mathrm{~kg} \mathrm{ha}^{-1}\right)$. As in the Fluvisol, significantly lower grain yield was obtained by inoculation with the remaining strains without and with $20 \mathrm{~kg} \mathrm{~N} \mathrm{ha}^{-1}\left(785-860 \mathrm{~kg} \mathrm{ha}^{-1}\right)$ as well as in $\mathrm{N}_{20} \varnothing$ fertilized control $\left(780 \mathrm{~kg} \mathrm{ha}^{-1}\right)$. In addition, as in the Fluvisol, untreated control $(\varnothing)$ gave the lowest grain yield $\left(710 \mathrm{~kg} \mathrm{ha}^{-1}\right)$.

The effect of bradyrhizobial inoculation on grain yield depended on treatments and soil types and it was expressed by percentage of grain yield increase in respect to untreated control- $\varnothing$ (Table 2).

Inoculation with single strains increased the grain yield by $23-53 \%$ in the Fluvisol as well as by $11-28 \%$ in the Humofluvisol over control- $\varnothing$ (Table 2). Combined treatments of inoculation and $20 \mathrm{~kg} \mathrm{~N}^{-1}$ increased the grain yield by $28-59 \%$ in the Fluvisol and by $11-31 \%$ in the Humofluvisol. In addition, fertilization with $40 \mathrm{~kg} \mathrm{~N} \mathrm{ha}^{-1}$ increased grain yield by 62 and $26 \%$, in the Fluvisol and Humofluvisol, respectively. Among inoculated treatments the highest percentage of grain yield increase was realized in treatments with strain 542 on the both soil types.

Data showed that quality of grain was also higher in the Fluvisol (by $28-70 \%$ according to total $\mathrm{N}$ content) than that in the Humofluvisol (Table 2). Percentage of $\mathrm{N}$ varied from 4.00 to $4.82 \%$ in the Fluvisol while in the Humofluvisol was lower and more variably; from 3.60 to $4.64 \%$.

In Fluvisol location, total $\mathrm{N}$ content (TNC) and protein yields were in correlation with grain yield. Combined treatment of strain 542 and $20 \mathrm{~kg} \mathrm{~N}^{-1}$ as well as $\mathrm{N}_{40} \varnothing$ fertilized control recorded the same values of TNC, 60.13 and $60.15 \mathrm{~kg} \mathrm{ha}^{-1}$, respectively. The greatest values of protein yield were also in these treatments (about $370 \mathrm{~kg}$ $\mathrm{ha}^{-1}$ ). Significantly lower TNC and protein yield had grain in treatments with 542 strain inoculation alone (56.46 and $353 \mathrm{~kg} \mathrm{ha}^{-1}$, respectively) and in combined treatment of 526 strain (53.30 and $333 \mathrm{~kg} \mathrm{ha}^{-1}$, respectively). In $\mathrm{N}_{20} \varnothing$ fertilized control and treatments with remaining strains 
Table 2. Grain yield of mungbean (Vigna radiata (L.) Wilczek) and its quality in inoculated treatments with single bradyrhizobial strains and in combination with $\mathrm{N}$ mineral fertilizer on different soil types.

\begin{tabular}{|c|c|c|c|c|c|c|c|c|}
\hline \multirow[b]{2}{*}{ Soil type } & \multicolumn{2}{|c|}{ Treatment $^{\star}$} & \multirow{2}{*}{$\begin{array}{c}\text { Grain } \\
\text { yield } \\
\text { kg ha }^{-1}\end{array}$} & \multirow{2}{*}{$\begin{array}{c}\% \text { grain } \\
\text { yield } \\
\text { increase } \\
\text { over } \varnothing\end{array}$} & \multirow[b]{2}{*}{$\% \mathrm{~N}$} & \multirow{2}{*}{$\begin{array}{l}\text { Total N } \\
\text { content } \\
\text { kg ha }^{-1}\end{array}$} & \multirow{2}{*}{$\begin{array}{c}\text { Fixed } \\
\text { N kg ha }^{-1} \\
(\%)\end{array}$} & \multirow{2}{*}{$\begin{array}{c}\text { Protein } \\
\text { yield } \\
\mathbf{k g ~ h a}^{-1}\end{array}$} \\
\hline & Strain & $\begin{array}{c}\mathbf{N} \\
\begin{array}{c}\text { Fertilizer kg } \\
\mathrm{ha}^{-1}\end{array}\end{array}$ & & & & & & \\
\hline \multirow[t]{11}{*}{ Fluvisol } & \multirow{2}{*}{542} & 0 & $1245^{\mathrm{ab}}$ & 153 & 4.53 & $56.46^{\mathrm{b}}$ & $23.82^{a}$ & $353^{b}$ \\
\hline & & 20 & $1301^{a}$ & 159 & 4.62 & $60.13^{\mathrm{a}}$ & $12.94^{\mathrm{b}}$ & $378^{\mathrm{a}}$ \\
\hline & \multirow{2}{*}{526} & 0 & $1135^{c}$ & 139 & 4.39 & $49.87^{\mathrm{cd}}$ & $17.23^{b}$ & $312^{\text {de }}$ \\
\hline & & 20 & $1167^{b c}$ & 143 & 4.57 & $53.30^{b c}$ & $6.11^{c}$ & $333^{b c}$ \\
\hline & \multirow{2}{*}{ Knj } & 0 & $1058^{d}$ & 130 & 4.59 & $48.55^{\mathrm{de}}$ & 15.91 & $303^{\mathrm{de}}$ \\
\hline & & 20 & $1174^{\mathrm{bc}}$ & 144 & 4.48 & $52.63^{c}$ & $5.44^{\mathrm{C}}$ & $329^{\text {bcd }}$ \\
\hline & \multirow{2}{*}{525} & 0 & $1007^{d}$ & 123 & 4.56 & $45.95^{\mathrm{e}}$ & $13.31^{b}$ & $287^{e}$ \\
\hline & & 20 & $1042^{d}$ & 128 & 4.82 & $50.18^{\mathrm{cd}}$ & $2.99^{c}$ & $314^{\mathrm{cd}}$ \\
\hline & $\varnothing$ & 0 & $816^{\mathrm{e}}$ & 100 & 4.00 & $32.64^{\dagger}$ & 0 & $204^{\dagger}$ \\
\hline & $\mathrm{N}_{20} \varnothing$ & 20 & $1028^{d}$ & 126 & 4.59 & $47.19^{e}$ & 0 & $295^{\mathrm{e}}$ \\
\hline & $\mathrm{N}_{40} \varnothing$ & 40 & $1325^{\mathrm{a}}$ & 162 & 4.54 & $60.15^{\mathrm{a}}$ & 0 & $376^{\mathrm{a}}$ \\
\hline LSD 0.05 & & & 76 & & & 3.46 & 3.39 & 23 \\
\hline \multirow[t]{11}{*}{ Humo fluvisol } & \multirow{2}{*}{542} & 0 & $910^{\mathrm{a}}$ & 128 & 3.73 & $33.92^{\mathrm{C}}$ & $8.36^{a}$ & $290^{c d}$ \\
\hline & & 20 & $930^{\mathrm{a}}$ & 131 & 3.80 & $35.31^{b c}$ & $4.11^{b c}$ & $309^{b c}$ \\
\hline & \multirow{2}{*}{526} & 0 & $790^{c d}$ & 111 & 3.62 & $28.56^{\mathrm{e}}$ & $3.00^{c}$ & $256^{\mathrm{e}}$ \\
\hline & & 20 & $860^{b}$ & 121 & 3.75 & $32.27^{d}$ & $1.07^{d}$ & $273^{\text {de }}$ \\
\hline & \multirow{2}{*}{ Knj } & 0 & $785^{d}$ & 111 & 4.41 & $34.60^{\circ}$ & $9.04^{a}$ & $292^{\mathrm{bcd}}$ \\
\hline & & 20 & $820^{c}$ & 115 & 4.30 & $35.27^{\mathrm{bc}}$ & $4.07^{b c}$ & $316^{b}$ \\
\hline & \multirow{2}{*}{525} & 0 & $805^{c d}$ & 113 & 4.38 & $35.28^{b c}$ & $9.72^{\mathrm{a}}$ & $276^{\text {de }}$ \\
\hline & & 20 & $790^{\text {cd }}$ & 111 & 4.64 & $36.62^{b}$ & $5.42^{b}$ & $302^{b c}$ \\
\hline & $\varnothing$ & 0 & $710^{\mathrm{e}}$ & 100 & 3.60 & $25.56^{\dagger}$ & 0 & $160^{f}$ \\
\hline & $\mathrm{N}_{20} \varnothing$ & 20 & $780^{d}$ & 110 & 4.00 & $31.20^{\mathrm{cd}}$ & 0 & $195^{d}$ \\
\hline & $\mathrm{N}_{40} \varnothing$ & 40 & $897^{\mathrm{a}}$ & 126 & 4.36 & $39.11^{\mathrm{a}}$ & 0 & $361^{a}$ \\
\hline LSD 0.05 & & & 34 & & & 1.40 & 1.51 & 23 \\
\hline
\end{tabular}

${ }^{*} \varnothing$-untreated control; $\varnothing_{20} \mathrm{~N}$ and $\varnothing_{40} \mathrm{~N}$-uninoculated, $\mathrm{N}$ fertilizer controls with $\mathrm{N}$ content of 20 and $40 \mathrm{~kg}^{-1}$ haspectively; Bradyrhizobium spp. strains with or without mineral $\mathrm{N}$ of $20 \mathrm{~kg} \mathrm{ha}^{-1} \mathrm{~N}$; Means with the same letter within a column do not differ significantly $(P<0.05)$.

with and with out application of $\mathrm{N}$ mineral fertilizer, TNC and protein yield varied from 45.95 to $53.30 \mathrm{~kg} \mathrm{ha}^{-1}$ and from 287 to $333 \mathrm{~kg} \mathrm{ha}^{-1}$. These data indicated that fertilization of $20 \mathrm{~kg} \mathrm{~N} \mathrm{ha}^{-1}$ in combination with inoculation by effective strain 542 could be applied for quality grain in the Fluvisol and can replace fertilization of $40 \mathrm{~kg} \mathrm{~N} \mathrm{ha}^{-1}$. In Humofluvisol location, grain yield increase was not followed by N\% increase in grain as well as TNC and protein yield except in fertilized control; the highest TNC and protein yield in grain (39.1 and $\left.361.01 \mathrm{~kg} \mathrm{ha}^{-1}\right)$ were reached in fertilized control in the Humofluvisol. Despite of its greatest grain yield, combined treatment of strain 542 and $20 \mathrm{~kg} \mathrm{~N} \mathrm{ha}^{-1}$ did not have the best quality due to lower value of $\mathrm{N} \%(3.73 \%)$. There were no clear differences between treatments based on quality of grain. The similar quality of grain had all treatments with strain 525, 542 and $\mathrm{Knj}$ (with and without $\mathrm{N}$ fertilizer). However, considering the highest obtained grain yield, strain 542 in combination with $20 \mathrm{~kg} \mathrm{ha}^{-1}$ can be recommended for application in the Humofluvisol. The lowest quality of grain (TNC of $25.56 \mathrm{~kg} \mathrm{ha}^{-1}$ ) was noted in the control treatment $(\varnothing)$ on the booth soil types which was in line with grain yield.

These results indicated that in investigated soil types inoculation with the strain 542 gave high grain yield while high quality of grain obtained in its combination with 
Table 3. Quantity and quality of shoot dry matter of mungbean (Vigna radiata (L.) Wilczek) in inoculated treatments with single bradyrhizobial strains and in combination with fertilization by mineral $\mathrm{N}$ on different soil types.

\begin{tabular}{|c|c|c|c|c|c|c|c|c|}
\hline \multirow[b]{2}{*}{ Soil type } & \multicolumn{2}{|c|}{ Treatment $^{\star}$} & \multirow{2}{*}{$\begin{array}{c}\text { Shoot dry } \\
\text { weight } \\
\text { (SDW) kg } \\
\text { ha }^{-1}\end{array}$} & \multirow{2}{*}{$\begin{array}{c}\% \text { SDW } \\
\text { increase } \\
\text { over } \varnothing\end{array}$} & \multirow[b]{2}{*}{$\% N$} & \multirow{2}{*}{$\begin{array}{l}\text { Total N } \\
\text { content } \\
\text { kg ha }^{-1}\end{array}$} & \multirow{2}{*}{$\begin{array}{c}\text { Fixed } \\
\mathbf{N} \\
\text { Content } \\
\%\end{array}$} & \multirow{2}{*}{$\begin{array}{c}\text { Protein } \\
\text { yield } \\
\text { kg ha }^{-1}\end{array}$} \\
\hline & Strain & $\begin{array}{c}\text { Mineral N } \\
\text { kg ha }^{-1}\end{array}$ & & & & & & \\
\hline \multirow[t]{11}{*}{ Fluvisol } & \multirow[b]{2}{*}{542} & 0 & $8786^{\mathrm{bc}}$ & 132 & 2.29 & $201.52^{\text {cd }}$ & $72.53^{b}$ & $1260^{\text {cd }}$ \\
\hline & & 20 & $8666^{\mathrm{bc}}$ & 130 & 2.35 & $203.25^{c d}$ & $41.06^{d}$ & $1270^{\text {cd }}$ \\
\hline & \multirow{2}{*}{526} & 0 & $8453^{b c}$ & 127 & 2.19 & $185.50^{\mathrm{e}}$ & $56.51^{c}$ & $1156^{\mathrm{e}}$ \\
\hline & & 20 & $9807^{a}$ & 148 & 2.27 & $222.25^{b}$ & $60.06^{b c}$ & $1389^{b}$ \\
\hline & \multirow{2}{*}{ Knj } & 0 & $8231^{c}$ & 124 & 2.43 & $199.72^{\mathrm{cd}}$ & $70.73^{\mathrm{bc}}$ & $1247^{d}$ \\
\hline & & 20 & $7517^{d}$ & 113 & 2.26 & $169.56^{\dagger}$ & $7.37^{\mathrm{e}}$ & $1060^{f}$ \\
\hline & \multirow{2}{*}{525} & 0 & $8408^{b c}$ & 126 & 2.33 & $196.28^{d}$ & $67.29^{b c}$ & $1227^{d}$ \\
\hline & & 20 & $8991^{b}$ & 135 & 2.77 & $249.32^{a}$ & $87.13^{\mathrm{a}}$ & $1557^{\mathrm{a}}$ \\
\hline & $\varnothing$ & 0 & $6649^{e}$ & 100 & 1.94 & $128.99^{g}$ & 0 & $806^{9}$ \\
\hline & $\mathrm{N}_{20} \varnothing$ & 20 & $7440^{d}$ & 112 & 2.18 & $162.19^{\dagger}$ & 0 & $1040^{f}$ \\
\hline & $\mathrm{N}_{40} \varnothing$ & 40 & $8769^{b c}$ & 132 & 2.40 & $210.37^{c}$ & 0 & $1316^{c}$ \\
\hline LSD 0.05 & & & 444 & & & 10.53 & 10.99 & 65 \\
\hline \multirow[t]{11}{*}{ Humo fluvisol } & \multirow{2}{*}{542} & 0 & $7805^{\mathrm{cd}}$ & 133 & 3.00 & $234.15^{\mathrm{abc}}$ & $116.35^{\mathrm{a}}$ & $1463^{b}$ \\
\hline & & 20 & $7570^{\text {de }}$ & 129 & 3.42 & $258.89^{a}$ & $73.89^{b}$ & $1617^{a}$ \\
\hline & \multirow{2}{*}{526} & 0 & $7734^{d}$ & 131 & 2.96 & $228.93^{b c}$ & $111.13^{\mathrm{a}}$ & $1431^{b}$ \\
\hline & & 20 & $8342^{a}$ & 142 & 2.05 & $254.01^{\mathrm{ab}}$ & $69.01^{\mathrm{bc}}$ & $1587^{\mathrm{a}}$ \\
\hline & \multirow{2}{*}{ Knj } & 0 & $7400^{\mathrm{ef}}$ & 126 & 2.44 & $180.56^{d}$ & $62.76^{\mathrm{c}}$ & $1128^{\mathrm{e}}$ \\
\hline & & 20 & $7137^{f}$ & 121 & 2.95 & $210.54^{\mathrm{C}}$ & $25.54^{\mathrm{e}}$ & $1316^{c}$ \\
\hline & \multirow{2}{*}{525} & 0 & $7600^{\text {de }}$ & 129 & 2.21 & $167.96^{d}$ & $50.16^{d}$ & $1047^{\dagger}$ \\
\hline & & 20 & $8020^{\mathrm{bc}}$ & 136 & 2.35 & $188.47^{d}$ & $3.47^{\dagger}$ & $1178^{d}$ \\
\hline & $\varnothing$ & 0 & $5890^{g}$ & 100 & 2.00 & $117.80^{\mathrm{e}}$ & 0 & $736^{9}$ \\
\hline & $\mathrm{N}_{20} \varnothing$ & 20 & $7385^{\mathrm{ef}}$ & 125 & 2.50 & $185 \mathrm{~d}$ & 0 & $1154^{d}$ \\
\hline & $\mathrm{N}_{40} \varnothing$ & 40 & $8110^{\mathrm{ab}}$ & 138 & 2.70 & $218.97^{b c}$ & 0 & $1368^{c}$ \\
\hline LSD 0.05 & & & 267 & & & 22.07 & 7.87 & 44 \\
\hline
\end{tabular}

${ }^{*} \varnothing$-untreated control; $\varnothing_{20} \mathrm{~N}$ and $\varnothing_{40} \mathrm{~N}$-uninoculated, $\mathrm{N}$ fertilizer controls with $\mathrm{N}$ content of 20 and $40 \mathrm{~kg}^{-1}$ haspectively; Bradyrhizobium spp. strains with or without mineral $\mathrm{N}$ of $20 \mathrm{~kg} \mathrm{ha}^{-1} \mathrm{~N}$; Means with the same letter within a column do not differ significantly $(\mathrm{P}<0.05)$.

$20 \mathrm{~kg} \mathrm{~N} \mathrm{ha}^{-1}$. In both cases these treatments can replace fertilization of $40 \mathrm{~kg} \mathrm{~N} \mathrm{ha}^{-1}$.

\section{Biomass production}

The effect of bradyrhizobial inoculation on quantity and quality of SDM yield of mungbean on the both soil types was presented in Table 3. In Fluvisol, inoculation with strain 526 in combination with $20 \mathrm{~kg} \mathrm{~N}^{-1}$ gave significantly the greatest shoot dry weight (SDW), $9.807 \mathrm{t}$ ha $^{-1}$ (Table 3). There were no clear differences between the remaining treatments with exception of significantly the lowest SDW noted in combined treatment of strain
Knj and $20 \mathrm{~kg} \mathrm{~N} \mathrm{ha}^{-1}$ and untreated control (Ø) (6.649 t $\left.\mathrm{ha}^{-1}\right)$. The second greatest yield was obtained in combined treatment of strain 525 and $20 \mathrm{~kg} \mathrm{~N}^{-1}$. Based on shoot dry weight, all bradyrhizobial strains showed the same effectiveness with exception of strain Knj which showed lower SDW.

Similarly to the results of grain yield, in Humiofluvisol all treatments gave lower shoot dry yield than in Fluvisol. The highest shoot dry weight was as in treatment in Fluvisol: inoculation with strain 526 in combination with $20 \mathrm{~kg} \mathrm{~N} \mathrm{ha}^{-1}\left(8.342 \mathrm{t} \mathrm{ha}^{-1}\right)$. There were no significant differences between this treatment and $\mathrm{N}_{40} \varnothing$-fertilized control $\left(8.11 \mathrm{t} \mathrm{ha}^{-1}\right)$. Significantly lower values of SDW were obtained by inoculation with single strains 542 
Table 4. Correlation coefficient for plant characters in mungbean inoculated with bradyrhizobial strains with and without mineral fertilizer of $20 \mathrm{~kg} \mathrm{~N}$ ha-1.

\begin{tabular}{lcccccc}
\hline & $\begin{array}{c}\text { Grain } \\
\text { yield }\end{array}$ & $\begin{array}{c}\text { Shoot dry } \\
\text { weight }\end{array}$ & $\begin{array}{c}\text { Grain total N } \\
\text { content }\end{array}$ & $\begin{array}{c}\text { Shoot total } \\
\text { N content }\end{array}$ & $\begin{array}{c}\text { Grain } \\
\text { fixed N }\end{array}$ & $\begin{array}{c}\text { Shoot } \\
\text { fixed N }\end{array}$ \\
\hline Grain yield & 1 & & & & & \\
Shoot dry weight & $0.697^{*}$ & 1 & & & & \\
Grain total N content & $0.969^{* *}$ & $0.718^{* *}$ & 1 & & & \\
Shoot total N content & 0.208 & $0.616^{*}$ & 0.143 & 1 & & \\
Grain fixed N & 0.446 & 0.399 & 0.460 & 0.044 & 1 & 1 \\
Shoot fixed N & 0.052 & 0.383 & -0.022 & $0.624^{*}$ & 0.459 & 1 \\
\hline
\end{tabular}

${ }^{*} \mathrm{P}<0.05$ (significant), ${ }^{* *} \mathrm{P}<0.01$ (highly significant), ${ }^{* \star *} \mathrm{P}<0.001$ (extremely significant).

$\left(7.805 \mathrm{t} \mathrm{ha}^{-1}\right)$ and $525\left(7.600 \mathrm{t} \mathrm{ha}^{-1}\right)$ without significant differences between them.

Inoculation influenced SDW increase by $24-32 \%$ in Fluvisol as well as by $26-33 \%$ in HumoFluvisol compared to untreated control- $\varnothing$ while combined treatments increased SDW by $13-48 \%$ and $21-42 \%$ in Fluvisol and Humofluvisol, respectively (Table 3). $\mathrm{N}_{40} \varnothing$ fertilized control in the both soil types increased SDW by 32 and $38 \%$ in respect to untreated control $(\varnothing)$. The highest percentage of shoot yield increase was in combined treatments of strain 526 and $20 \mathrm{~kg} \mathrm{~N} \mathrm{ha}^{-1}$ on the both soil types.

Percentage of $\mathrm{N}$ in shoot dry matter of inoculated treatments varied from 2.19 to $2.77 \%$ and from 2.21 to $3.00 \%$ in Fluvisol and Humofluvisol, respectively. Slightly higher $\% \mathrm{~N}$ had the plants simultaneously inoculated and fertilized in respect to only inoculated plants.

The best quality in Fluvisol had combined treatment of strain 525 and $20 \mathrm{~kg} \mathrm{~N} \mathrm{ha}^{-1}$ (249.32 kg ha ${ }^{-1}$ of TNC and $1.557 \mathrm{t} \mathrm{ha}^{-1}$ of protein yield) while significantly lower quality was detected also in combined treatment of strain $526\left(222.25 \mathrm{~kg} \mathrm{ha}^{-1}\right.$ of TNC and $1.389 \mathrm{t} \mathrm{ha}^{-1}$ of protein yield). In Humofluvisol the best quality had combined treatments of strains $526\left(254.01 \mathrm{~kg} \mathrm{ha}^{-1}\right.$ of TNC and $1587 \mathrm{~kg} \mathrm{ha}^{-1}$ of protein yield) and strain $542(258.89 \mathrm{~kg}$ $\mathrm{ha}^{-1}$ of TNC and $1617 \mathrm{~kg} \mathrm{ha}^{-1}$ of protein yield).

These results indicated that in investigated soil types inoculation with the strain 526 in combination with $20 \mathrm{~kg}$ $\mathrm{N} \mathrm{ha}^{-1}$ gave the highest yield and one of the highest quality of SDM and can replace fertilization of $40 \mathrm{~kg} \mathrm{~N} \mathrm{ha}^{-1}$, while strain 542 gave the highest quality in Humofluvisol. Based on quality and quantity of SDM obtained by inoculation with single strain, strains 526 and 542 showed high efficiency in the both soil types.

\section{Fixed $\mathbf{N}$ in the grain and shoot dry matter}

Amount of grain fixed $\mathrm{N}$ in the both soil types was low: in Fluvisol was up to $12.94 \mathrm{~kg} \mathrm{ha}^{-1}$ in combined treatments and $23.82 \mathrm{~kg} \mathrm{ha}^{-1}$ in treatments with inoculation alone while in Humofluvisol was less than $10 \mathrm{~kg} \mathrm{ha}^{-1}$. Also, the percentage of fixed nitrogen in grain total $\mathrm{N}$ content showed that $\mathrm{N}$-fixing activity of strains was higher in the Fluvisol $(29-42 \%)$ than in the Humofluvisol (11-26\%) (Table 2).

Amount of fixed $\mathrm{N}$ was higher in shoot matter than that in the grain. In SDM single strains fixed $56.51-72.53 \mathrm{~kg} \mathrm{~N}$ $\mathrm{ha}^{-1}$ and $49.78-116.35 \mathrm{~kg} \mathrm{~N}$ ha $^{-1}$ in Fluvisol and Humofluvisol, respectively which is $31-36 \%$ and $30-50 \%$ of total $\mathrm{N}$ content in SDM in Fluvisol and Humofluvisol, respectively (Table 3 ).

The strain 542 fixed $\mathrm{N}$ in SDM and the grain with the highest effectiveness on the both soil types Taking into account high efficiency of strain 542 and its high grain yield, we can conclude that strain 542 was more effective and has the greatest potential to be active agent of microbiological $\mathrm{N}$ fertilizer.

\section{Correlation coefficient}

Correlation coefficient between plant characters in mungbean - bradyrhizobium associations (Table 4) in the both soil types, indicated that grain yield was in positive significant correlation with SDW $(r=0.697)$ and grain total $\mathrm{N}$ content $(r=0.969)$. In addition, there is significant correlation between SDW and shoot $(r=0.616)$ and grain $(r=0.718)$ total $N$ content. Shoot fixed $N$ was in significant correlation with shoot total $\mathrm{N}$ content $(\mathrm{r}=$ 0.624).

\section{ANOVA}

In our investigation mungbean was evaluated for their symbiotic performances with four bradyrhizobial strains with and without $\mathrm{N}$ mineral fertilizer. The effects of the strain, mineral $\mathrm{N}$ and soil type on the variation of SNF were measured by three factorial analysis of variance for SDW and grain yield. Plant SDW is the best parameter to evaluate symbiotic activity of legume-Rhizobium associations while seed yield is an important trait as it measures the economic productivity in mungbean. Based on three 
Table 5. Analysis of variance for shoot dry weight and grain yield of mungbean inoculated with four bradyrhizobial strains.

\begin{tabular}{|c|c|c|}
\hline Source of variance & Shoot dry weight $\left(\mathrm{kg} \mathrm{ha}^{-1}\right)$ & Grain yield $\left(\mathrm{kg} \mathrm{ha}^{-1}\right)$ \\
\hline Strain & ${ }^{\mathrm{s}} 126.37^{* * *}$ & $81.76^{* * *}$ \\
\hline Type of soil & $214.40^{* * *}$ & 854.54 *** \\
\hline N & $50.72^{* * *}$ & $45.79^{* * *}$ \\
\hline \multicolumn{3}{|l|}{ Interactions } \\
\hline Strain $x$ type & $5.65^{\star *}$ & $12.69^{* * *}$ \\
\hline Strain $\times N$ & $33.35^{\star \star *}$ & $4.12^{* *}$ \\
\hline Type x N & $0.06^{\mathrm{ns}}$ & $8.74^{* *}$ \\
\hline Strain $x$ type $\times N$ & $5.33^{* *}$ & $3.13^{*}$ \\
\hline
\end{tabular}

${ }^{\mathrm{s}} \mathrm{F}$-values, ${ }^{*},{ }^{* *},{ }^{* * *}$ Significant at $\mathrm{P}<0.05,0.01$ and 0.001 , respectively.

factorial variance analysis, it was found that bradyrhizobial strains, mineral $\mathrm{N}$ application of $20 \mathrm{~kg} \mathrm{ha}^{-1}$, type of soil had highly significant $(P<0.001)$ effects alone on SDW and grain yield on the both soil types (Table 5). Shoot dry weight was significantly affected by interaction between strain $x$ type $(P<0.01)$ and strain $x$ type $x N$ $(P<0.01)$ as well as by strain $x N(P<0.001)$ but not by type $\times \mathrm{N}$. Interactions of all factors in their combinations affected significantly grain yield.

\section{DISCUSSION}

Nitrogen fixing effectiveness of particular bradyrhizobial strains was the object of many investigations on mungbean with the aim of highly effective strain selection (Hafeez et al., 2001; Neeraj et al., 2008). The previous pot experiment in a semi-controlled greenhouse environment showed $\mathrm{N}$ fixing ability of specific rhizobial strains to mungbean (Delić et al., 2007). Highly effective strains from this pot experiment were chosen for checking their $\mathrm{N}$ fixing effectiveness in field condition. In the presented field trial, $\mathrm{N}$ fixing ability of these effective strains to mungbean for better quantity and quality of grain and SDM as well as reduced use of $\mathrm{N}$ mineral fertilizer was studied in two different soil types; Fluvisol and Humofluvisol.

Absence of nodules on plant roots of untreated control$\varnothing$ (data not shown) indicated that there were no indigenous rhizobial strains specific for mungbean in Fluvisol and Humofluvisol fields of presented study. This could be the consequence of a legume absence on investigated field locations because rhizobial soil count gradually decreases in parallel with the increase of the time elapsed from the presence of host plants in croprotation (Bottomley and Jenkins, 1983).

An adequate $\mathrm{N}$ supply for legumes is essential for normal plant growth and seed yield. The concentration of $\mathrm{N}$ containing solutes in the soil, especially that of nitrate may change quickly due to the processes such as uptake by plant roots and microorganisms, leaching and gentrification.

Therefore, it is recommended to apply appropriate amount of $\mathrm{N}$ mineral fertilizer directly before sowing even though a soil is well supplied with $\mathrm{N}$ (Mengel and Kirkby, 2001) as in presented trial. Application of $\mathrm{N}$ mineral fertilizers improves the plant productivity and enhances the grain yield (Rahman et al., 2002; Sarma and Sarma, 1999). Some authors have reported an increase in grain yield with increased level of $\mathrm{N}$ mineral fertilizer (Rahman et al., 2002; Sadeghipour et al., 2010; Ali et al., 1999; Nadeem et al., 2004). In mungbean production application of mineral $\mathrm{N}$ fertilizer varies from $15-90 \mathrm{~kg} \mathrm{~N}$ $\mathrm{ha}^{-1}$ depending on soil type and form of soil $\mathrm{N}$ available for the plant (Ahmad et al., 2001; Mahboob and Asghar, 2002). In native area (South and Southern Asia) mungbean is grown without application of mineral $\mathrm{N}$ fertilizer or with $10-20 \mathrm{~kg} \mathrm{~N}^{-1}$ (Ali, 2011; Ullah et al., 2011). In the presented trial the highest grain yield of mungbean was obtained in fertilized control treatment with $40 \mathrm{~kg} \mathrm{~N} \mathrm{ha}^{-1}$, in Fluvisol which is in agreement with results of some authors (Ayub et al., 1999; Mozumder et al., 2003). There is a level of $\mathrm{N}$ which represents an optimum supply for given crop on a particular soil type. Adding more mineral $\mathrm{N}$ fertilizer than an optimum amount does not increase yield and crop quality and will not be taken up by the crop usuallydue to the leaching to ground water. In addition, an important environmental factor which interferes with $\mathrm{N}_{2}$ fixation is the presence of more mineral $\mathrm{N}$ in the soil, usually as nitrate $\left(\mathrm{NO}_{3}^{-}\right)$(Heridge et al., 2005). Because of that, good management of $\mathrm{N}$ fertilization with particular reference to optimum amount of fertilizers is important for maximum growth of crop, enhancement of grain yield as well as $N_{2}$ fixation (Kaushal et al., 2006).

Many researches confirmed that inoculation of mungbean with effective rhizobial strains increase plant height and dry matter production as well as seed yield (Brar and Lal, 1991; Thakur and Panwar, 1995; Provorov et al., 1998; Sharma, 2001; Anjum et al., 2006; Mansoor, 2007). In this trial the inoculation of mungbean crop with bradyrhizobial strains significantly increased grain yield 
(from 11-53\%) which is in concordance with findings of some authors (Mansoor, 2007). A significant effect of strains on grain yield was detected in our trail $(P<0.001)$. Presented results showed that plant inoculation only with strain 542 enabled one of the highest grain yield that was not significantly different than grain yield obtained in fertilized control- $\mathrm{N}_{40} \varnothing$ which is in agreement with results of some authors (Mansoor et al., 2007). Based on grain quality, the second highly effective strain in Fluvisol was the strain 526 while in Humofluvisol it was 525.

However, some researches showed that the best grain yield was obtained by combined application of rhizobial inoculation and $\mathrm{N}$ mineral fertilizer (Provorov et al., 1998; Kashem et al., 2000; Ashraf et al., 2003; Nadeem et al., 2004; Anjum et al., 2006). Shivesh et al. (2000) reported that Bradyrhizobium inoculation and NPK fertilizer significantly increase the grain and straw yields of mungbean. Application of $20 \mathrm{~kg} \mathrm{~N}^{-1}$ by Tripathi et al. (1994) and Rahman et al. (2002) resulted in seed yield which was statistically similar with rhizobial inoculation alone. These results and data of mungbean $\mathrm{N}$ fertilization (Sadeghipour et al., 2010) as well as applied amount of $40 \mathrm{~kg} \mathrm{~N} \mathrm{ha}^{-1}$ in $\mathrm{N}_{40} \varnothing$-fertilized control directed our trial to research inoculation in combination with $20 \mathrm{~kg} \mathrm{~N} \mathrm{ha}^{-1}$. Presented results indicated that combined treatments of inoculation and $20 \mathrm{~kg} \mathrm{ha}^{-1}$ enabled a slightly better quality and quantity of grain and SDW than treatments with inoculation alone.

According to our results in the both soil types, inoculation with the strain 542 gave one of the highest grain yield while the highest quality of grain was obtained also by $\mathrm{N}$ fixing ability of the strain 542 but in combination with $20 \mathrm{~kg} \mathrm{~N}$ ha. The nitrogen directly increases the plant protein content in the shoot and grain of Vigna (Shadi et al., 2002; Sadeghipour et al., 2010). Presented results indicated that the most effective strain proved to be Bradyrhizobium strain 542 which in combination with 20 $\mathrm{kg} \mathrm{N} \mathrm{ha}^{-1}$ could replace application of $40 \mathrm{~kg} \mathrm{~N} \mathrm{ha}^{-1}$ on the both soil types.

Introduction of food legume into new areas faces the crop with new environmental conditions. Information of environmental factors effect on improvement of crop growth is important in development of appropriate management practices. One of the major causes of low crop yield is decline of soil fertility. Type of soil is one of the most important factor influencing the yield of mungbean which significant influence was confirmed in presented research by analysis of variance for shoot dry weight and grain yield of mungbean $(P<0.001)$. In general, Vigna radiata has ability to grow vigorously under wide range of environmental condition and different soil types without addition supplement N (Rafiei, 2009). However, some studies suggested that plant growth in most temperate ecosystems is limited by combination of $\mathrm{N}$ and water (Reed et al., 2007). In this trial growing potential of mungbean in agro-ecological condition in Serbia which belongs to the temperate continental climate zone was investigated. Approximately about 360 000 ha of a Fluvisol and Humofluvisol soils are used as arable field in Serbia. It makes them the important soil types in Serbia. Fluvisols cover 5\% of Europe (Soil Atlas of Europe, 2005). They have chemical characteristic that can be suitable for crop cultivation while physical composition of Humoflivisol is less suitable for plant growing. Humofluvisol contains more clay in respect to Fluvisol (at a depth of entire soil profile the clay content was above $45 \%$ ). Prevalence of small pores in Humofluvisol makes infiltration and drainage slow and negatively influence yield of mungbean.

In addition, two dry periods in 2007 (in the middle of April and in the end of June to the beginning of August with $21.6 \mathrm{~mm}$ rainfall in July) as well as maximal temperature of $31.4^{\circ} \mathrm{C}$ in July (Figure 1) influenced decrease of mungbean yield in Humofluvisol. In spite of grate amount of rainfall that was expressed in 2007, uneven rainfall distribution during the plant growing period had negative influence on yield attributes. In wet period at the beginning of vegetation Humofluvisol was more than wet with possible anaerobic processes but in dry period was tough and compacted with insufficient quantity of water accessible to the plants. These unfavourable environmental conditions could be one of the reasons for lower yield and plant quality of mungbean in Humofluvisol compared to Fluvisol. The process of $\mathrm{N}_{2}$ fixation is sensitive to soil water decrease resulting in reduction of SDW as well as nodule number and weight (Ramos et al., 2003). In addition, high temperature influence persistence of rhizobial populations in the soils (Mansoor, 2007). However, thanks to the fact that mungbean is drought tolerant crop that can overcome adverse environmental condition (Anjum et al., 2006; Sheteawi and Tawfik, 2007; Abbas et al., 2011) in the presented trial mungbean has obtained the grain yield up to $930 \mathrm{~kg} \mathrm{ha}^{-1}$ and SDW of about $8300 \mathrm{~kg} \mathrm{ha}^{-1}$ in the Humofluvisol.

The highest grain yield of $1300 \mathrm{~kg} \mathrm{ha}^{-1}$ (by $59 \%$ over control- $\varnothing$ ) obtained in Fluvisol pointed out possible good grain yield potential of mungbean in Serbian agroecological conditions which is in line with results of Tien et al. (2002). In addition, this value is in concordance with report of Mansoor (2007) that mungbean has the potential to produce seed yield higher than $1200 \mathrm{~kg} \mathrm{ha}^{-1}$. This was similar with results of FAO that the highest seed yields were recorded in growing countries like China $\left(1286 \mathrm{~kg} \mathrm{ha}^{-1}\right)$, Japan $\left(1119 \mathrm{~kg} \mathrm{ha}^{-1}\right)$ and Italy (1210 kg $\mathrm{ha}^{-1}$ ) while the potential of mungbean to produce seed yield in Pakistan is $1200 \mathrm{~kg}$ (Mansoor, 2007). In the presented trial the grain yield from 710 to $1300 \mathrm{~kg} \mathrm{ha}^{-1}$ was obtained. Untreated control ( $\varnothing)$ gave the lowest grain yield which is general findings of many scientific papers (Brar and Lal, 1991; Rajput et al., 1992; Rahman et al., 2002; Mansoor, 2007). In addition, values of grain yield in untreated controls in the presented trial indicated the big gap between potential and average yield of 
mungbean (Mansoor, 2007).

Good yield performance can be achieved by proper combination of agro technical measures (Sarkar et al 2004; Rajput et al., 1992; Nazir 1996; Boe et al., 1991; El Karamany, 2006; Mansoor, 2007; Sadeghipour, 2008). In this trial appropriate time of sowing, plant density and line to line spacing were applied to provide available sunlight and aeration as well as more space and nutrition in the root zone. They influenced effective nitrogen fixation (Talee et al., 1999; Rafiei, 2009). These agro technical measures resulted in satisfactory grain and shoot yield in Serbian agro-ecological condition without significant weed quantity and absence of plant protection during the period of vegetation. In addition, rhizobial inoculation positively influenced the grain yield $(P<0.001)$ which is in agreement with Provorov et al. (1998).

According to the results of some authors, Rhizobium inoculation in the field trial increased the grain yield by about $10 \%$ more than no inoculation (Adreshna et al., 1993; Sharma and Khurana, 1997). Similar results were obtained in our experiment in Humofluvisol (by 11-13\% over untreated control- $\varnothing$ ) with exception for inoculation with strain 542 which increase grain yield much higher, by $28 \%$ over control- $\varnothing$. However, percentage of grain yield increase was higher in Fluvisol depending on strain and reached up to $53 \%$ with strain 542 , compared to untreated control- $\varnothing$. Presented results of protein yield were in line with those reported by Rafiei (2009).

According to the presented results application of $20 \mathrm{~kg}$ $\mathrm{N}$ ha $^{-1}$ in $\mathrm{N}_{20} \varnothing$ fertilizer treatment was statistically comparable with rhizobial inoculation which is in concordance with results of some authors (Tripathi et al., 1994; Rahman et al., 2002). Ayub et al. (1999) recorded $31 \%$ higher grain yield than control with $40 \mathrm{~kg} \mathrm{~N} \mathrm{ha}^{-1}$ while in presented trial the increase of grain yield in the fertilized control depended on soil types; according to the presented results in Humofluvisol grain yield was lower $(26 \%)$ but in Fluvisol doubled (62\%) than untreated control- $\varnothing$ indicating suitable soil characteristics for plant growing in Fluvisol.

Grain production of mungbean can follow its forage production. According to some authors mungbean can be used as dual-purpose crop; using its shoot matter and after its cuttings growing to the grain. However, its potential as dual-purpose crop is not clearly lighted. When seed production is the main object, mungbean can produce forage dry yield of about 4-5 t ha ${ }^{-1}$ and 2.62$2.76 \%$ of $\mathrm{N}$ depending on DAS (El Karamany, 2006). In this experiment quantity and quality of shoot dry matter of mungbean was investigated with the aim to use this plant as forage crop.

The nitrogen deficiency results in plant yield decrease (Sadeghipour et al., 2010). Presented results showed that inoculation with single rhizobial strains in Fluvisol and Humofluvisol increased the SDW in respect to untreated control- $\varnothing$ which is in agreement with findings of Provorov et al. (1998) and Hayat et al. (2008). Amount of
DSM of $9.8 \mathrm{t} \mathrm{ha}^{-1}$ was in line with results of Tien et al. (2002). Inoculation with single strain 542 and 526 increased the shoot dry yield by about $30 \%$ in the both soil types which was equal to application of $40 \mathrm{~kg} \mathrm{~N}$ ha in fertilized control. The combined treatment of inoculation and $20 \mathrm{~kg} \mathrm{~N} \mathrm{ha}^{-1}$ increased the SDW for $13-48 \%$ and 21 $42 \%$, in Fluvisol and Humofluvisol, respectively. Mineral $\mathrm{N}$ and its interaction with strains highly influenced SDW $(P<0.001)$ as well as grain yield $(P<0.01)$. Our results indicated good quality of plant shoot dry matter in all inoculated treatments which is confirmed with results of Tien et al. (2002), El Kamarany (2006) and Rafiei (2009).

Our data of fixed $\mathrm{N}$ revealed that mungbean fixed substantial but variable quantities of $\mathrm{N}$ per hectare which is in agreement with data of Hayat et al. (2008). The most effective strain 542 fixed approximately 76 and $116 \mathrm{~kg} \mathrm{~N}$ $\mathrm{ha}^{-1}$ in Fluvisol and Humofluvisol, respectively which is more than fixation of effective rhizobial and bradyrhizobial strains in symbiosis with mungbean (about $55-60 \mathrm{~kg} \mathrm{~N}$ $\mathrm{ha}^{-1}$ ) in some papers (Hayat and Ali, 2004; Mansoor, 2007). The total amount of fixed $\mathrm{N}$ is the resultant of proportion of plant fixed $\mathrm{N}$ and total $\mathrm{N}$ content accumulated in the crop (Hayat and Ali, 2004). According to the presented results coefficient of correlation showed that shoot fixed $\mathrm{N}$ was influenced by shoot total $\mathrm{N}$ content which is in agreement with the results of Hayat et al. (2008).

Genetic variation and environment were the object of investigation of some researchers (Atta and Shah, 2009; Ullah et al., 2011). Two tested soil types influenced the differences in mungbean growth in our trial. In addition, there were differences between inoculated treatments with and without $\mathrm{N}$ mineral fertilizer as in research of Atta and Shah (2009) and Ullah et al. (2011). In combined treatments on the both soil types, grain and shoot fixed $\mathrm{N}$ were mainly significantly lower in respect to inoculation alone since plants prefers mineral $\mathrm{N}$ in respect to $\mathrm{N}_{2}$ from the air (Herridge et al., 1998).

Analysis of variance showed that strain, type of soil and mineral $\mathrm{N}$ and their interactions significantly effected shoot dry weight and grain yield. This suggested further investigation on different soil type, with high effective strains and different amount of mineral $\mathrm{N}$ for effective production of mungbean in symbiotic association with bradyrhizobial and rhizobial strains.

Presented results exhibited effectiveness of strains 542 and 526. According to the protein yield and total and fixed $\mathrm{N}$ content increase, strain 542 was highly effective without significant differences in comparison to its treatment in combination with mineral $\mathrm{N}$.

\section{Conclusion}

All investigated characteristics of grain and SDM yield were significantly increased due to seed inoculation with particular rhizobial strains, with and with out $20 \mathrm{~kg} \mathrm{~N} \mathrm{ha}^{-1}$. 
Shoot dry matter and grain yield were significantly influenced by bradyrhizobial strains, soil types, mineral $\mathrm{N}$ and their interaction. The combined application of seed inoculation with $B$. japonicum strain 542 and fertilization of $20 \mathrm{~kg} \mathrm{~N} \mathrm{ha}^{-1}$ gave high quantity and quality of grain and SDM yield and can replace fertilization of $40 \mathrm{~kg} \mathrm{~N}$ ha ${ }^{1}$. This strain might be recommended as active agent of $\mathrm{N}$ microbiological fertilizer. Mungbean can be successfully grown as a food and forage crop in Fluvisol and Humofluvisol soils.

\section{ACKNOWLEDGEMENT}

This research was supported by the Ministry of Science and Environmental Protection of Republic of Serbia, Project, No TR-46007 and TR-20098.

\section{REFERENCES}

Abbas G, Abbas Z, Aslam M, Malik AU, Ishaque M, Hussain F (2011). Effects of organic and inorganic fertilizers on mungbean (Vigna radiata (L.) yield under arid climate. Int. Res. J. Plant Sci., 2: 094098.

Adreshna PB, Modhwadia MM, Khanpara VD, Petel JC (1993). Response of mungbean (Vigna radiata L.) to nitrogen, phosphorus and Rhizobium inoculation. Indian J. Agron., 38: 490-492.

Ahmad T, Hefeez FY, Mahmood T, Malik KA (2001). Residual effect of nitrogen fixed by mungbean (Vigna radiata) and blackgram (Vigna mungo) on subsequent rice and wheat crops. Aust. J. Exp. Agric., 41: 245-248.

Ali A, Malik MA, Chaudhry MA, Siddique MA, Rafique M (1999). Growth and yield response of mungbean (Vigna radiata L.) to different seed rates and levels of phosphorous. Pak. J. Biol. Sci., 2: 879-880.

Ali M (2011). Tropical pulse crop. Directorate of pulse research, Kampur, India. www.fertilizer.org/ifa/content/download/8944.

Anjum MS, Ahmed ZI, Rauf CA (2006). Effect of Rhizobium inoculation and nitrogen fertilizer on yield and yield components of mungbean. Int. J. Agric. Biol., 2: 238-240.

Ashraf M, Mueen-ud-Din M, Warraich NH (2003). Production efficiency of mungbean (Vigna radiata L.) as affected by seed inoculation and NPK application. Int. J. Agric. Biol., 2: 179-180.

Atta BM, Shah TM (2009). Stability analysis of elite chickpea genotypes tested under diverse environments. Aust. J. Crop Sci., 3: 249-256.

Ayub M, Tanveer A, Choudhry MA, Amin MMZ, Murtaza G (1999). Growth and yield response of rrtungbean (Vigna radiata L.) cultivars at varying levels of nitrogen. Pak. J. Biol. Sci., 2: 1378-1380.

Boe A, Twidwell EK, Kephart KD (1991). Growth and forage yield of cowpea and mungbean in the Northern Great Plains. Can. J. Plant Sci., 71: 709 -715.

Bottomley PJ, Jenkins MB (1983). Some characteristics of Rhizobium meliloti isolates from alfalfa fields in Oregon. Soil Sci. Soc. Am. J., 47: 1153-1157.

Brar JS, Lal PB (1991). Effect of Rhizobium inoculation, phosphorus and molybdenum on yield and its components in mungbean. Indian Agriculturist 35: 67-9.

Brouns $F$ (2002): Soya isoflavones: a new and promising ingredient for the health foods sector. Food Res. Int., 35: 187-193.

Delić D, Stajković O, Rasulć N, Kuzmanović Đ, Pivić R, Jošić D, Miličić B (2007). Uticaj sojeva određenih vrsta rizobia na azotofiksacionu sposobnost zelene vigne, Vigna radiata (L.) Wilczek. Zbornik radova Instituta za ratarstvo i povrtarstv, 44: 439-445

El Karamany MF (2006). Double purpose (forage and seed) of mungbean production 1-Effect of plant densityand forage cutting dateon forage and seed yields of mungbean (Vigna radiata L. Wilczck). Res. J. Agric. Biol. Sci., 2: 162-165.
Hafeez FY, Hameed S, Ahmad T, Malik KA (2001). Competition between effective and less effective strains of Bradyrhizobium spp. for nodulation on Vigna radiata. Biol. Fertil. Soils, 33: 382-386.

Hayat R, Ali S (2004): Potential of summer legumes to fix nitrogen and benefit wheat crop under rainfed condition. J. Agronomy 3: 273-281.

Hayat R, Ali S, ljaz SS, Chatha TH, Siddique MT (2008). Estimation of n2-fixation of mung bean and mash bean through xylem ureide technique under rainfed conditions. Pak. J. Bot., 40: 723-734.

Herridge DF, Marcellos H, Felton WL, Turner GL, Peoples MB (1998). Chickpea in wheat-based cropping systems of northern New South Wales. III. Prediction of N2 fixation and N balance using soil nitrate at sowing and chickpea yield. Aust. J. Agric. Res., 49: 409-418.

Herridge DF, Robertson MJ, Cocks B, Peoples MB, Holland JF, Heuke $L$ (2005). Low nodulation and nitrogen fixation of mungbean reduce biomass and grain yields. Aust. J. Exp. Agric., 45, 269-277. IUSS Working Group WRB. 2007. World Reference Base for Soil Resources 2006, first update 2007. World Soil Resources Reports No. 103. FAO, Rome.

Kashem MA, Mian MH, Rahman MF (2000). Effect of Bradyrhizobium on the yield of mungbean (Vigna radiata L.) grown in Ganges Tidal floodplain soil. J. Agric. Res., 38: 407-412.

Kaushal T, Onda M, Ito S, Yamazaki A, Fujikake H, Ohtake N, Sueyoshi K, Takahashi Y, Ohyama T (2006). Effect of Deep Placement of Slow-release Fertilizer (Lime Nitrogen) Applied at Different Rates on Growth, N2 Fixation and Yield of Soya Bean (Glycine max [L.] Merr.) J. Agron. Crop Sci., 192: 417-426.

Khan A, Malik MA (2001). Determing biological yield potential of different mungbean cultivars. J. Biol. Sci., 1: 575-576.

Mahboob A, Asghar M (2002). Effect of seed inoculation and different nitrogen levels on the grain yield of mungbean. Asian J. Plant Sci., 4: 314-315.

Mansoor M (2007). Evaluation of various agronomic management practices for increased productivity of Mungbean (Vigna radiata L. Wilczek). PhD thesis. Department of Agronomy Faculty of Agriculture Gomal University Dera Ismail Khan: 1-163. http://eprints.hec.gov.pk/2430/1/2285.htm.

Mengel K, Kirkby EA (2001). Principles of plant nutrition, 5th Edition. Kluwer Academic Publishers, Netherlands.

Mozumder SN, Salim M, Islam M, Nazrul Ml, Zaman MM (2003). Effect of Bradyrhizopus inoculums at different nitrogen levels on summer mungbean. Asian J. Plant Sci., 2: 817-822.

Mpepereki S, Javaheri F, Davis P, Giller KE (2000). Soybeans and sustainable agriculture: promiscuous soybeans in Southern Africa. Field Crops Res., 65: 137-149.

Musiyiwa K, Mpepereki S, Giller KE (2005). Symbiotic effectiveness and host ranges of indigenous rhizobia nodulating promiscuous soyabean varieties in Zimbabwean soils. Soil Biol. Biochem., 37: 1169-1176.

Myers RL (2000). Mungbeans: A Food Legume Adapted to Hot, Dry Conditions, In: Alternative Crop Guide, Published by Thomas Jefferson Institute Columbia, MO USA. http://www.jeffersoninstitute.org/pubs/mungbean.shtml.

Nadeem MA, Ahmad R, Ahmad M.S (2004). Effect of seed inoculation and different fertilizer levels on the on the growth and yield of mungbean (Vigna radiata L.). J. Agron., 3: 40-42.

Nazir S (1996). Crop production. Grain legumes. National Book Foundation. Islamabad: p. 306

Neeraj T, Gaurav SS, Sachin T, Chandra M (2008). Selection and evaluation of Rhizobial strains of Vigna radiata L. beneficial to biological nitrogen fixation. Afr. J. Biotechnol., 7: 3683-3685.

Provorov NA, Saimnazarov UB, Bahromov IU, Pulatova DZ, Kozhemyakov AP, Kurbanov GA (1998). Effect of rhizobia inoculation on the seed (herbage) production of mungbean (Phaseolus aureus Roxb.) grown at Uzbekistan. J. Arid Environ., 39: 569-575.

Rafiei M (2009). Influence of tillage and plant density on mungbean. Am.-Eurasian J. Sustain. Agric., 3: 877-880.

Rahman MA, Islam N, Islam A, Hassan MK, Talukder MMR (2002). Yield performance of Mungbean (Vigna radiata L. Wilczck) CV Barimung-4 as Influenced by Rhizobium inoculation and NPK Fertilizer. Pak. J. Biol. Sci., 5: 146-148.

Rajput HA, Masood T, Jamil M, Afzal CM (1992). Response of mungbean (Vigna radiata) to NPK fertilizers under irrigated conditions. J. Agric. Res., 30: 485-488. 
Ramos MLG, Parsons R, Sprent JI, James EK (2003). Effect of water stress on nitrogen fixation and nodule structure of common bean. Pesq. Agropec. Bras., 38: 339-347.

Reed SC, Seastedt TR, Mann CM, Suding KN, Townsed AR, Cherwin $\mathrm{KL}$ (2007). Phosphorus fertilization stimulates nitrogen fixation and increases inorganic nitrogen concentration in a restored prairie. Appl. Soil Ecol., 36: 238-242.

Reedy KC, Soffes AR, Prine GM (1986). Tropical legumes for green manure: I Nitrogen production and the effects on succeeding crop yield. Agron J., 78: 1-4.

Remans R, Ramaekers L, Schelkens S, Hernandez G, Garcia A, Reyes LJ, Mendez N, Toscano V, Mulling M, Galvez L, Vanderleyden J (2008) Effect of Rhizobium-Azospirillum coinoculation on nitrogen fixation and yield of two contrasting Phaseolus vulgaris $\mathrm{L}$. genotypes cultivated across different environments in Cuba. Plant Soil, 321: 2537.

Sadeghipour O (2008). Response of Mungbean varieties to different sowing dates. Pak. J. Biol. Sci., 11: 2048-2050.

Sadeghipour O, Monem R, Tajali AA (2010). Production of Mungbean (Vigna radiata L.) as affected by nitrogen and phosphorus fertilizer application. J. Appl. Sci., 10: 843-847.

Sarkar AR, Kabir H, Begum M, Salam A (2004). Yield performance of mungbean as affected by planting date, variety and plant density. J. Agric. Sci., 31: 352-359.

Sarma CK, Sarma HK (1999). Effect of different production factros on growth, yield and conomics of mungbean (Vigna radiata L.). Indian J. Hill Farming, 12: 29-31.

Shady S, Raya Y, Khan K (2002). Effects of phosphorus and Rhizobium inoculation on the protein contents of green gram. Int. J. Agric. Biol., 5: $179-180$.

Sharma P, Khurana AS (1997). Effect of single and multi-strain Rhizobium inoculants on biological nitrogen fixation in summer mungbean, Vigna radiata (L.) Wilczek. Res. Dev. Rep., 14: 8-11.

Sharma S (2001). Growth, physiological and yield aspects of mungbean (Vigna radiata) as affected by inoculation treatment by different strains of Bradyrhizobium culture. I. J. Res. Crop, 2: 112-115.

Sheteawi SA, Tawfik KM (2007). Interaction effect of some biofertilizers and irrigation water regime on mung bean (Vigna radiata) growth and yield. J. Appl. Sci. Res., 3: 251-262.
Škorić A, Filipovski G, Ćirić M (1985). Klasifikacija zemljišta Jugoslavije, Akademija nauka i umjetnosti Bosne i Hercegovine, Sarajevo.

Soil Atlas of Europe 2005: European Soil Bureau Network, European Commision, 2005 , http://eusoils.jrc.ec.europa.eu/projects/soil_atlas/download.cfm.

Somasegaran P, Hoben HJ (2004) Handbook for rhizobia. Methods in legume Rhizobium technology. Springer, New York.

Talee AR, Bandeh NK, Gholamie B (1999). Effect of sowing date on grain yield, yield components and percentage of protein in green gram cultivars. Iranian J. Agric. Sci., 29: 751-758.

Thakur AK, Panwar JDS (1995). Effect of Rhizobium -VAM interactions on growth and yield in mungbean (Vigna radiata L.) under field conditions. Indian J. Plant Pathol., 38: 62-65.

Tien HH, Hien TM, Son MT, Herridge D (2002). Rhizobial inoculation and $\mathrm{N}_{2}$ fixation of soybean and mungbean in the eastern region of South Vietnam. In: Herridge, D. (ed.), Inoculants and Nitrogen Fixation of Legumes in Vietnam, 109e Proceedings, Vietnam 17-18 February 2001, ACIAR, pp. 29-36.

Tripathi ML, Namdeo KN, Tiwaari KP, Kurmvanshi SM (1994). Relative efficiency of nitrogen and rhizobium inoculation on growth and yield of kharief pulsed and oil seed. Crop Res. Hisar., 7: 328-333.

Ullah H, Khali IH, Iltafullah, Rahman HU, Amin I (2011). Genotype x environment interaction, heritability and selection response for yield and yield contributing traits in mungbean. Afr. J. Biotechnol., 10: 475483.

Vincent MJ (1970). A manual for the practical study of the root nodule bacteria. IBP Handbook no. 15. Blackwell Scientific Publications, Oxford.

Vlassak KM, Vanderleyden J (1997). Factors influencing nodule occupancy by inoculant rhizobia. Crit. Rev. Plant Sci., 16, 163-223. 